\title{
OPEN Antibacterial activity and mechanism of plant flavonoids to gram-positive bacteria predicted from their lipophilicities
}

\author{
Ganjun Yuan ${ }^{1,2 \bowtie}$, Yingying Guan ${ }^{1}$, Houqin $\mathrm{Yi}^{1}$, Shan Lai ${ }^{1,2}$, Yifei Sun ${ }^{1} \&$ Seng Cao ${ }^{1,2}$
}

Antimicrobial resistance seriously threatened human health, and new antimicrobial agents are desperately needed. As one of the largest classes of plant secondary metabolite, flavonoids can be widely found in various parts of the plant, and their antibacterial activities have been increasingly paid attention to. Based on the physicochemical parameters and antibacterial activities of sixty-six flavonoids reported, two regression equations between their $A C D / \operatorname{LogP}$ or $\log _{7.40}$ and their minimum inhibitory concentrations (MICs) to gram-positive bacteria were established with the correlation coefficients above 0.93 , and then were verified by another sixty-eight flavonoids reported. From these two equations, the MICs of most flavonoids against gram-positive bacteria could be roughly calculated from their $A C D / \log P$ or $\log _{7.40}$, and the minimum MIC was predicted as approximately 10.2 or 4.8 $\mu \mathrm{M}$, more likely falls into the range from 2.6 to $10.2 \mu \mathrm{M}$, or from 1.2 to $4.8 \mu \mathrm{M}$. Simultaneously, both tendentiously concave regression curves indicated that the lipophilicity is a key factor for flavonoids against gram-positive bacteria. Combined with the literature analyses, the results also suggested that the cell membrane is the main site of flavonoids acting on gram-positive bacteria, and which likely involves the damage of phospholipid bilayers, the inhibition of the respiratory chain or the ATP synthesis, or some others.

Antimicrobial resistance (AMR) has been seriously threatened human public health and global economic development, and new antimicrobial agents are desperately needed ${ }^{1,2}$. Antibiotics, as the secondary metabolites produced by many bacteria, actinomycetes and fungi, showed remarkably antimicrobial activities, while they also bring some toxic side effects to human body, and are unavoidable to lead to the resistance ${ }^{3}$. Many plant ingredients present weaker antimicrobial activities, while some of them can reverse the resistance of antimicrobial agents $^{4}$. Simultaneously, most of them are considered nontoxic to human body because of their ubiquity in all sorts of plant derived foods and beverages.

As one of the largest classes of plant secondary metabolite, flavonoids can be widely found in various parts of the plants, such as fruit, vegetables, nuts and tea ${ }^{4}$. These compounds have a wide range of pharmacological activities including antibiosis, antioxidation, and coronary heart disease prevention, etc. It is worth noting that some flavonoids can enhance the sensitivity of bacteria to antibiotics, and even reverse the $\mathrm{AMR}^{4,5}$. Thereout, the antibacterial activities of flavonoids have been paid more and more attention to. Recently, several investigations were performed for the antimicrobial activities of flavonoids, and the probable relationships between their chemical structures and antimicrobial activities were also summarized ${ }^{4-6}$. However, the regularity conclusions on the structure-activity relationships of flavonoids against bacteria still need to be further explored.

During our researches on antimicrobial agents ${ }^{7-9}$, it is vaguely found that the antimicrobial activities of flavonoids are not related to their special structure, while may be related to their polarities or lipid-water partition coefficients. Many data of plant flavonoids, involving their chemical structures and antibacterial activities reported in previous papers, were searched and analyzed for proving it. The inhibitory activities of plant flavonoids against gram-positive bacteria especially Staphylococcus aureus can be widely searched, while those against gram-negative ones and fungi were reported too few to carry out statistical analyses ${ }^{4,6}$. Thereby, the former was our focus in this research. As the inhibitory activities of a compound against different pathogenic bacteria are

${ }^{1}$ Laboratory of Natural Medicine and Microbiological Drug, College of Bioscience and Bioengineering, Jiangxi Agricultural University, Nanchang 330045, China. ${ }^{2}$ Biotechnological Engineering Center for Pharmaceutical Research and Development, Jiangxi Agricultural University, Nanchang 330045, China. ${ }^{\square}$ email: gyuan@jxau.edu.cn 
<smiles>C=C(C)C(CCC(C)(C)O)Cc1c2c(O)cc(O)c1C(c1ccc(O)cc1O)CC2=O</smiles>

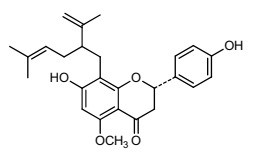

6

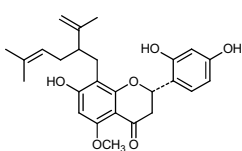

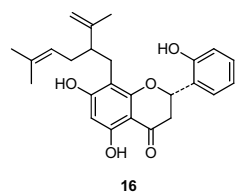<smiles>CC(C)=CCC(C)C(CO)Cc1c2c(O)cc(C)c1C(=O)CC(c1ccc(O)cc1O)O2</smiles>

2<smiles>CC(C)=CCc1c(O)cc2c(c1C)C(=O)CC(c1cc(O)c(O)cc1O)O2</smiles>

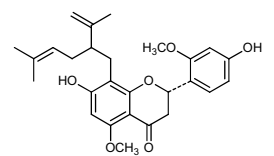

12<smiles>CC(C)=CCc1cc(O)cc(O)c1C1CC(=O)CC(c2ccc(O)cc2O)O1</smiles>

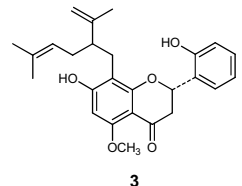<smiles>CC(C)=CCc1c(O)cc(O)c2c1OC(c1ccccc1O)CC2=O</smiles>

4<smiles>C=C(C)C(=O)CCc1c(O)cc(C)c2c1OC(c1ccc(O)cc1O)C(=O)C2O</smiles><smiles>C=C(C)C(CCC(C)(C)C)Cc1c(O)cc(O)c2c1OC(c1ccc(O)cc1O)CC2=O</smiles><smiles>C=C(C)C(C)CCc1c(O)cc(O)c2c1OC(c1ccc(O)cc1O)C(O)C(O)C2O</smiles><smiles>C=C(C)C(C)CCc1c(C)cc(O)c2c1OC(c1ccccc1O)CC2=O</smiles>

5<smiles>C=C(C)C(CCc1c(O)cc(C)c2c1OC(c1ccc(O)cc1O)CC2=O)CC(C)=C(C)C</smiles><smiles>C=C(C)C(CCC(C)(C)C)Cc1c(O)ccc2c1OC(c1ccc(O)cc1O)CC2=O</smiles>

15

Figure 1. Chemical structures of compounds 1 to $19^{10}$.

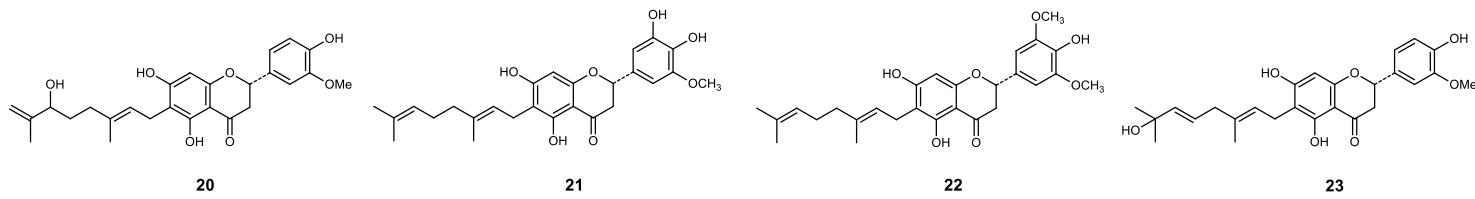

23

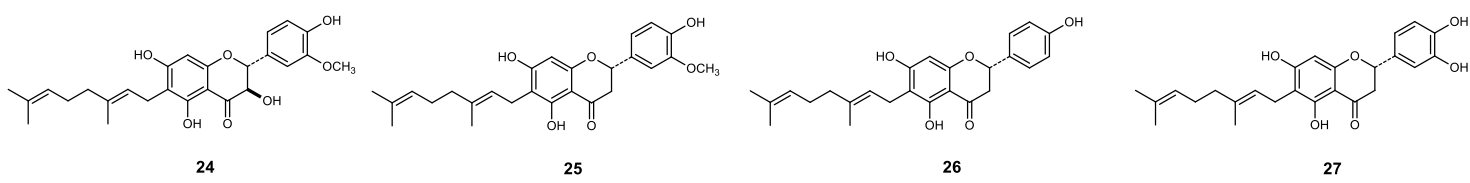

Figure 2. Chemical structures of compounds 20 to $27^{11}$.

varied, this paper will pay more attention to the inhibitory activities of these flavonoids against Staphylococcus aureus, a species most reported in the literature.

\section{Results}

Structure, antibacterial activity, and physicochemical parameter. Sixty-six flavonoids (1 to 66) shown on Figs. 1, 2, 3, 4, 5 and 6, reported in six papers ${ }^{10-15}$, were selected for the preliminary structure-physicochemical parameter-activity analyses of plant flavonoids against gram-positive bacteria, especially Staphylococcus aureus. These flavonoids include three subclasses as flavonols, dihydroflavones and dihydroflavonols. Regression analyses indicated that no universal correlation between the antimicrobial activity (expressed as minimum inhibitory concentration, MIC) and the physicochemical parameter Gibbs energy, LogP (Partition coefficient), MR (Molar Refractivity), CMR (Calculated Molar Refractivity), tPSA (Topological Polar Surface Area), or solubility (SolDB) could be established for these flavonoids. However, probable correlations between the antimicrobial activities (MIC, or $\mathrm{MIC}_{90}$ which expressed as the MIC of a compound to $90 \%$ test isolates of a specific pathogen) and the physicochemical parameter CLogP (Calculated Partition coefficient), $\mathrm{ACD} / \log \mathrm{P}, \operatorname{or} \log \mathrm{D}_{7.40}$ ( $\log _{10}$ of distribution coefficient at $\mathrm{pH} 7.40$ ) were respectively discovered, and the physicochemical parameters and antimicrobial activities of these compounds were listed in Tables 1, 2, 3, 4, 5 and 6 for further analyses ${ }^{10-15}$.

Data analysis and correlation establishment. The regression analyses for the physicochemical parameters $C \log \mathrm{P}, \mathrm{ACD} / \log \mathrm{P}$, or $\log \mathrm{D}_{7.40}$ and the antimicrobial activities $\left(\mathrm{MIC}\right.$ or $\mathrm{MIC}_{90}$ ) of these flavonoids to a certain pathogenic bacterium were respectively performed, and their regression curves were showed on Fig. S1 to S6 in Supplementary Information. From these figures, nearly all regression curves indicate that the antibacterial activities of these flavonoids present similar change characteristics along with the increase of their $\log P$ or $\log \mathrm{D}_{7.40}$. First, the antibacterial activities will dramatically increase when the $\log \mathrm{P}$ or $\log \mathrm{D}_{7.40}$ increase up 


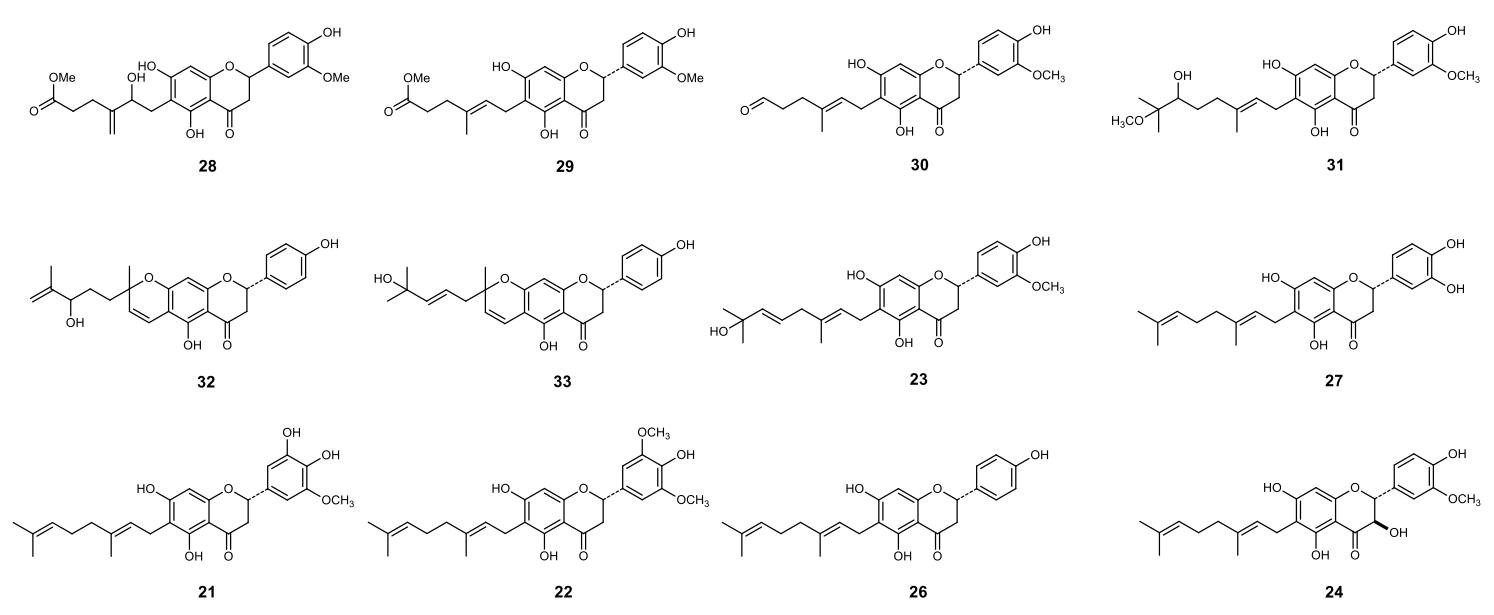

Figure 3. Chemical structures of compounds 21 to 24 , and 26 to $33^{12}$.

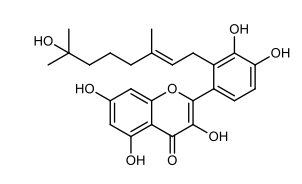

34

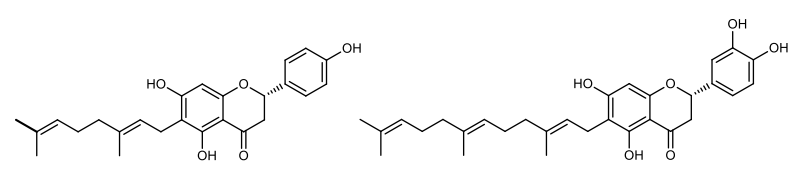

38

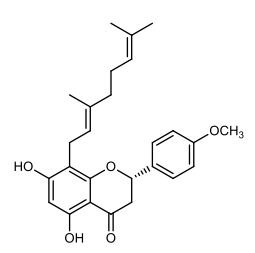

42

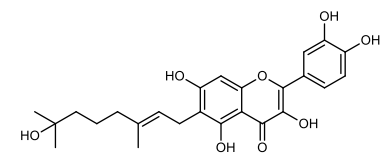

35

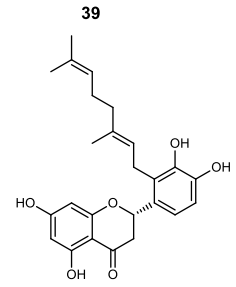

43

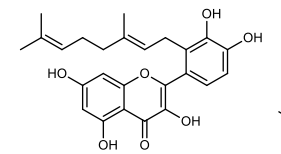

36
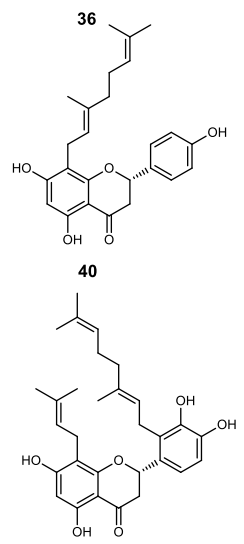

44

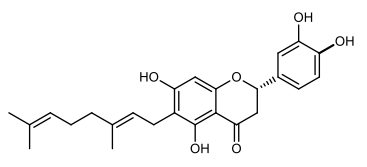

37

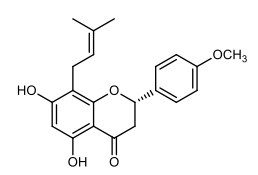

41

Figure 4. Chemical structures of compounds 34 to $\mathbf{4 4}{ }^{13}$.
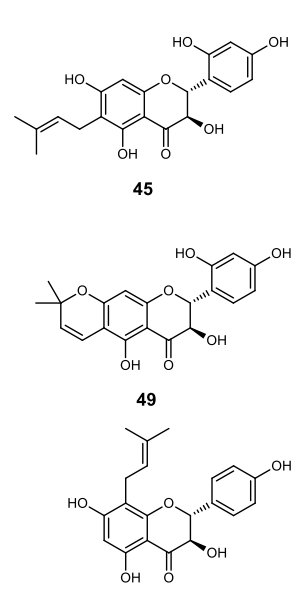

52

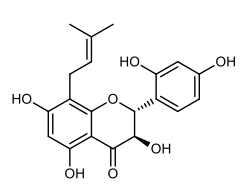

46

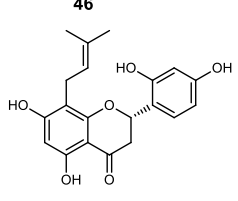

17

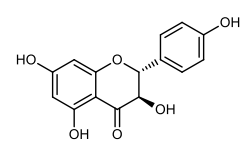

53

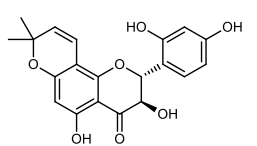

47

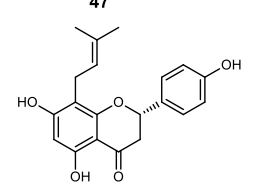

50

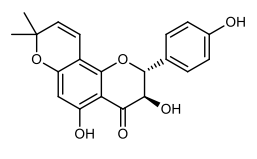

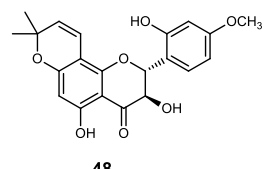

48<smiles>O=C1C[C@H](c2ccc(O)cc2)Oc2cc(O)cc(O)c21</smiles>

51

Figure 5. Chemical structures of compounds $\mathbf{1 7}$, and $\mathbf{4 5}$ to $\mathbf{5 4 ^ { 1 4 }}$. 
<smiles>CC(C)=CCC(CCc1c(O)cc(O)c2c1OC(c1ccc(O)cc1O)CC2=O)C(C)(C)C</smiles>

55<smiles>C=C(C)C(CC=C(C)C)Cc1c(O)cc2c(c1C(C)(C)C)C(=O)CC(c1c(O)cc(O)cc1O)O2</smiles><smiles>COc1cc(O)c(C2CC(=O)c3c(O)c(CC=C(C)C)c(O)c(CC(CC=C(C)C)CC(C)(C)C)c3O2)c(O)c1</smiles><smiles>CC(C)=CCC/C(C)=C/Cc1c(O)cc(O)c2c1OC(c1c(O)cc(O)cc1O)CC2=O</smiles>

60<smiles>CC=CCc1c(O)cc(O)c2c1OC(c1ccc(O)cc1O)CC2=O</smiles>

64<smiles>CC(C)=CCc1cccc(O)c1OCc1c(O)cc(O)cc1O</smiles><smiles>[B]/C(C)=C/CC/C(C)=C/Cc1cc(C2CC(=O)c3c(O)cc(O)cc3O2)c(O)cc1O</smiles>

61<smiles>CC(C)=CCC(CC(C)(C)C)c1c(O)cc(O)c2c1OC(c1ccccc1O)CC2=O</smiles>

65<smiles>CC(C)=CCC(CCc1c(O)cc(O)c2c1OC(c1c(O)cccc1O)CC2=O)C(C)(C)C</smiles>

58<smiles>CC(C)=CCC(Cc1c(O)cc(O)c2c1OC(c1c(O)cc(O)cc1O)CC2=O)C(C)(C)C</smiles>

62<smiles>O=C1CC(c2ccc(O)cc2)Oc2cc(O)cc(O)c21</smiles>

66

Figure 6. Chemical structures of compounds 55 to $66^{15}$.

\begin{tabular}{|c|c|c|c|c|c|}
\hline \multirow[b]{2}{*}{ Compounds } & \multirow[b]{2}{*}{ CLog $\mathrm{P}^{\mathrm{a}}$} & \multirow[b]{2}{*}{$\mathrm{ACD} / \log \mathrm{P}^{\mathrm{b}}$} & \multirow[b]{2}{*}{$\log D_{7.40}^{b}$} & \multicolumn{2}{|l|}{$\operatorname{MIC}(\mu \mathrm{M})^{c}$} \\
\hline & & & & S. aureus & B. subtilis \\
\hline 1 & 4.67 & 5.55 & 5.38 & $\mathrm{~L}$ & $\mathrm{~L}$ \\
\hline 2 & 4.08 & 5.09 & 4.92 & 11.3 & 11.3 \\
\hline 3 & 6.31 & 7.02 & 6.80 & 11.8 & 5.9 \\
\hline 4 & 4.35 & 5.29 & 5.09 & 14.7 & 14.7 \\
\hline 5 & 4.52 & 5.52 & 5.35 & - & - \\
\hline 6 & 6.36 & 7.02 & 6.81 & 23.7 & 23.7 \\
\hline 7 & 3.53 & 4.18 & 4.09 & 25.9 & 25.9 \\
\hline 8 & 3.58 & 4.18 & 3.98 & 25.9 & 25.9 \\
\hline 9 & 4.50 & 5.74 & 5.50 & 22.7 & 22.7 \\
\hline 10 & 5.58 & 6.52 & 6.33 & 5.9 & 5.9 \\
\hline 11 & 5.64 & 6.30 & 6.08 & 5.7 & 5.7 \\
\hline 12 & 6.46 & 7.05 & 6.83 & 5.5 & 5.5 \\
\hline 13 & 6.40 & 7.27 & 7.09 & 5.7 & 5.7 \\
\hline 14 & 3.86 & 4.80 & 4.63 & $\mathrm{~L}$ & $\mathrm{~L}$ \\
\hline 15 & 3.92 & 4.58 & 4.37 & $\mathrm{~L}$ & $\mathrm{~L}$ \\
\hline 16 & 6.25 & 7.24 & 7.06 & 12.2 & 6.1 \\
\hline 17 & 3.68 & 4.56 & 4.37 & 14.0 & 7.0 \\
\hline 18 & 4.57 & 5.53 & 5.26 & - & - \\
\hline 19 & 2.84 & 3.81 & 3.56 & - & - \\
\hline
\end{tabular}

Table 1. Physico-chemical parameters and antimicrobial activities of compounds 1 to $19^{10}$. ${ }^{a}$ The CLogP values were calculated using software ChemBioDraw Ultra 12.0. ${ }^{\mathrm{b}}$ The $\mathrm{ACD} / \log \mathrm{P}$ and $\log \mathrm{D}_{7.40}$ values were calculated using software ACD/Labs 6.0. ${ }^{\mathrm{c}} \mathrm{MIC}$, minimum inhibitory concentration; S. aureus, Staphylococcus aureus; $B$. subtilis, Bacillus subtilis; L, lower activity than other compounds while no data was given; -, no data was given.

to a specific value. Along with the further increase of $\log \mathrm{P}$ or $\log \mathrm{D}_{7.40}$, the antibacterial activities will first increase tendentiously and then decrease. Simultaneously, their regression equations between the physicochemical parameter $(x)$ and the MIC $(y)$, together with the correlation coefficients $(r)$, were respectively presented on Fig. S1 to S6, and summarily listed in Table 7. Most correlation coefficients ( $r$ ) were more than 0.90 (Table 7). This indicated that there is a good correlation between the physicochemical parameter CLogP, ACD/LogP, or $\log \mathrm{D}_{7.40}$ and the antimicrobial activities (MIC), of these flavonoids to a certain pathogenic bacterium. 


\begin{tabular}{|c|c|c|c|c|c|}
\hline \multirow[b]{2}{*}{ Compounds } & \multirow[b]{2}{*}{ CLogPa } & \multirow[b]{2}{*}{$\mathrm{ACD} / \log \mathrm{P}^{\mathrm{b}}$} & \multirow[b]{2}{*}{$\log D_{7.40} b$} & \multicolumn{2}{|c|}{$\operatorname{MIC}(\mu \mathrm{M})^{\mathrm{c}}$} \\
\hline & & & & S. aureus & S. epidermidis \\
\hline 20 & 4.22 & 5.56 & 5.34 & 35.2 & 70.4 \\
\hline 21 & 5.68 & 6.54 & 6.32 & 4.4 & 8.8 \\
\hline 22 & 6.01 & 6.61 & 6.39 & 8.5 & 8.5 \\
\hline 23 & 4.22 & 5.18 & 4.96 & $140.8^{\mathrm{d}}$ & $140.8^{\mathrm{d}}$ \\
\hline 24 & 5.15 & 6.25 & 5.97 & 4.4 & 4.4 \\
\hline 25 & 6.23 & 7.02 & 6.81 & 18.2 & 9.1 \\
\hline 26 & 6.38 & 7.32 & 7.12 & 19.6 & 9.8 \\
\hline 27 & 5.78 & 6.72 & 6.51 & 9.4 & 9.4 \\
\hline
\end{tabular}

Table 2. Physico-chemical parameters and antimicrobial activities of compounds 20 to $27^{11}$. ${ }^{\text {aThe }}$ CLogP values were calculated using software ChemBioDraw Ultra 12.0. ${ }^{\mathrm{b}}$ The $\mathrm{ACD} / \log \mathrm{P}$ and $\log \mathrm{D}_{7.40}$ values were calculated using software ACD/Labs 6.0. ' MIC, minimum inhibitory concentration; S. aureus, Staphylococcus

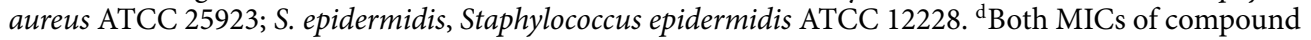
23 against S. aureus ATCC 25923 and S. epidermidis ATCC 12228 were more than $32 \mu \mathrm{g} / \mathrm{mL}(70.4 \mu \mathrm{M})$. As microdilution broth method was used to test MIC, we set $64 \mu \mathrm{g} / \mathrm{mL}(140.8 \mu \mathrm{M})$ as their MICs.

\begin{tabular}{|c|c|c|c|c|c|c|}
\hline \multirow[b]{2}{*}{ Compounds } & \multirow[b]{2}{*}{$C \log \mathrm{P}^{\mathrm{a}}$} & \multirow[b]{2}{*}{$A C D / \log P^{b}$} & \multirow[b]{2}{*}{$\log D_{7.40}^{b}$} & \multicolumn{3}{|l|}{$\operatorname{MIC}(\mu \mathrm{M})^{c}$} \\
\hline & & & & MRSA 6975 & MRSA 630 & MRSA 6205 \\
\hline 28 & 1.83 & 3.27 & 3.04 & 140.2 & $280.4^{\mathrm{d}}$ & $280.4^{\mathrm{d}}$ \\
\hline 29 & 3.68 & 4.60 & 4.38 & 36.2 & 144.6 & 72.3 \\
\hline 30 & 3.28 & 4.27 & 4.05 & 19.4 & 155.2 & 77.6 \\
\hline 31 & 3.91 & 4.67 & 4.46 & 32.9 & 263.2 & 263.2 \\
\hline 32 & 4.47 & 6.10 & 5.76 & 18.9 & 151.5 & 151.5 \\
\hline 33 & 4.47 & 5.63 & 5.29 & 37.9 & 151.5 & 151.5 \\
\hline 23 & 4.22 & 5.18 & 4.96 & 17.6 & 35.2 & 35.2 \\
\hline 27 & 5.78 & 6.72 & 6.51 & 18.8 & 37.7 & 37.7 \\
\hline 21 & 5.68 & 6.54 & 6.32 & 17.6 & 8.8 & 8.8 \\
\hline 22 & 6.01 & 6.61 & 6.39 & 17.1 & 17.1 & 8.5 \\
\hline 26 & 6.38 & 7.32 & 7.12 & 4.9 & 9.8 & 4.9 \\
\hline 24 & 5.15 & 6.25 & 5.97 & 8.8 & 8.8 & 17.6 \\
\hline
\end{tabular}

Table 3. Physico-chemical parameters and antimicrobial activities of compounds 21 to 24 , and 26 to $33^{12}$. ${ }^{\mathrm{a}}$ The $\mathrm{CLog} \mathrm{P}$ values were calculated using software ChemBioDraw Ultra 12.0. ${ }^{\mathrm{b}}$ The $\mathrm{ACD} / \mathrm{Log} \mathrm{P}$ and $\log \mathrm{D}_{7.40}$ values were calculated using software ACD/Labs 6.0. ' MIC, minimum inhibitory concentration; MRSA 6975, methicillin-resistant Staphylococcus aureus 6975; MRSA 630, methicillin-resistant Staphylococcus aureus 630; MRSA 6205, methicillin-resistant Staphylococcus aureus 6205. ${ }^{\mathrm{d}}$ The MICs of compound 28 against MRSA 630 and 6205 were more than $64 \mu \mathrm{g} / \mathrm{mL}(140.2 \mu \mathrm{M})$. As microdilution broth method was used to test MIC and the three physico-chemical parameters were small, we set $128 \mu \mathrm{g} / \mathrm{mL}(280.4 \mu \mathrm{M})$ as their MICs.

As we pointed out above, the antimicrobial activities of a compound against different pathogenic bacteria were varied, and even against the same one in different determination conditions. Thereby, the regression analyses were respectively performed for these flavonoids reported in different papers. Considering that the pathogenic bacteria used for antibacterial experiments mainly involved S. aureus, S. epidermidis, and B. subtilis, the same compound should present similar inhibitory activities and identical antibacterial mechanism to these gram-positive bacteria. Thereby, we put the physicochemical parameters and the average MICs to S. aureus, S. epidermidis, or/and $B$. subtilis (Tables 1, 2, 3, 4, 5 and 6), of these flavonoids together for further regression analyses. The results indicated that the correlation between CLogP and antibacterial activities (MICs) is weak with a correlation coefficient of 0.8412 , while that between $\mathrm{ACD} / \log \mathrm{P}$ or $\log \mathrm{D}_{7.40}(x)$ and MICs $(y)$ is more reliable (Fig. 7). The regression equations were respectively expressed as $y=-1.6745 x^{5}+56.143 x^{4}-741.93 x^{3}+4831.8 x^{2}-15531 x+19,805$ and $y=-1.1474 x^{5}+38.802 x^{4}-515.39 x^{3}+3361.9 x^{2}-10789 x+13,706$, with the correlation coefficients of 0.9349 and 0.9309 , respectively. These further proved, by a larger sample, that the inhibitory activities of these flavonoids to gram-positive bacteria will nonlinearly increase as the $\mathrm{ACD} / \log \mathrm{P}$ or $\log \mathrm{D}_{7.40}$ increase to approximately 7.0, and then decrease along with the further increase of $\mathrm{ACD} / \log \mathrm{P}$ or $\log \mathrm{D}_{7.40}$.

Verification. To verify the above correlations, other sixty-eight flavonoids (Fig. 8) including flavone, isoflavone, flavonol, flavanonol, dihydroflavone, dihydroisoflavone, flavane, and chalcone subclasses etc., reported in seven papers ${ }^{4,16-21}$, were selected for the comparison of theoretical and reported MICs. Using above two regres- 


\begin{tabular}{|c|c|c|c|c|c|}
\hline \multirow[b]{2}{*}{ Compounds } & \multirow[b]{2}{*}{ CLogPa } & \multirow[b]{2}{*}{$A C D / \log P^{b}$} & \multirow[b]{2}{*}{$\log _{7.40}{ }^{b}$} & \multicolumn{2}{|c|}{$\operatorname{MIC}(\mu \mathrm{M})^{c}$} \\
\hline & & & & S. aureus & B. subtilis \\
\hline 34 & 3.46 & 4.52 & 3.84 & 140.2 & \begin{tabular}{|l|}
140.2 \\
\end{tabular} \\
\hline 35 & 3.71 & 4.52 & 3.93 & 140.2 & 140.2 \\
\hline 36 & 5.18 & 6.20 & 5.53 & $\begin{array}{l}73.0 \\
\end{array}$ & 73.0 \\
\hline 37 & 5.78 & 6.72 & 6.51 & 9.5 & 9.5 \\
\hline 38 & 6.38 & 7.32 & 7.12 & 19.7 & 9.8 \\
\hline 39 & 7.81 & 8.75 & 8.54 & 32.6 & 16.3 \\
\hline 40 & 6.43 & 7.32 & 7.13 & 9.8 & 39.4 \\
\hline 41 & 4.98 & 5.94 & 5.75 & 90.8 & 90.8 \\
\hline 42 & 7.01 & 7.97 & 7.78 & 19.0 & 19.0 \\
\hline 43 & 5.78 & 6.74 & 6.5 & 37.9 & 37.9 \\
\hline 44 & 7.73 & \begin{tabular}{|l|l|}
8.84 & \\
\end{tabular} & \begin{tabular}{|l|l|}
8.64 \\
\end{tabular} & 8.2 & 16.3 \\
\hline
\end{tabular}

Table 4. Physico-chemical parameters and antimicrobial activities of compounds 34 to $44^{13}$. ${ }^{\text {a The CLogP }}$ values were calculated using software ChemBioDraw Ultra 12.0. ${ }^{\mathrm{b}}$ The $\mathrm{ACD} / \log \mathrm{P}$ and $\log \mathrm{D}_{7.40}$ values were calculated using software ACD/Labs 6.0. ' MIC, minimum inhibitory concentration; S. aureus, Staphylococcus aureus 209P; B. subtilis, Bacillus subtilis NBRC 3134.

\begin{tabular}{|c|c|c|c|c|c|}
\hline \multirow[b]{2}{*}{ Compounds } & \multirow[b]{2}{*}{ CLogP $\mathrm{P}^{\mathrm{a}}$} & \multirow[b]{2}{*}{$A C D / \log P^{b}$} & \multirow[b]{2}{*}{$\log D_{7.40}^{b}$} & \multicolumn{2}{|l|}{$\mathrm{MIC}_{90}(\mu \mathrm{M})^{\mathrm{c}}$} \\
\hline & & & & MRSA (22) & MSSA (7) \\
\hline 45 & 2.55 & 3.79 & 3.67 & 167.8 & 335.7 \\
\hline 46 & 2.60 & 3.79 & 3.53 & 167.8 & 167.8 \\
\hline 47 & 2.65 & 3.92 & 3.59 & 42.1 & 42.1 \\
\hline 48 & 3.42 & 4.67 & 4.35 & 81.4 & 40.6 \\
\hline 49 & 2.65 & 4.11 & 3.67 & 84.5 & 84.5 \\
\hline 17 & 3.68 & 4.56 & 4.37 & 175.4 & 350.8 \\
\hline 50 & 4.40 & 5.29 & 5.10 & 183.6 & 183.6 \\
\hline 51 & 2.44 & 3.19 & 2.96 & $>918.3$ & $>918.3$ \\
\hline 52 & 3.32 & 4.51 & 4.27 & 87.8 & 87.8 \\
\hline 53 & 1.37 & 2.42 & 2.11 & $1734.6^{\mathrm{d}}$ & $1734.6^{\mathrm{d}}$ \\
\hline 54 & 3.37 & 4.64 & 4.34 & 88.3 & 88.3 \\
\hline
\end{tabular}

Table 5. Physico-chemical parameters and antimicrobial activities of compounds $\mathbf{1 7}$, and $\mathbf{4 5}$ to $\mathbf{5 4}{ }^{14}$. ${ }^{\text {a The }}$ CLogP values were calculated using software ChemBioDraw Ultra 12.0. ${ }^{\mathrm{b}}$ The $\mathrm{ACD} / \log \mathrm{P}$ and $\log \mathrm{D}_{7.40}$ values were calculated using software $\mathrm{ACD} / \mathrm{Labs} 6.0 .{ }^{\mathrm{c}} \mathrm{MIC}_{90}$, minimum inhibitory concentration to $90 \%$ test isolates; MRSA (22), twenty-two isolates of methicillin-resistant Staphylococcus aureus; MSSA (7), seven isolates of methicillin-susceptible Staphylococcus aureus. ${ }^{\mathrm{d}}$ Both $\mathrm{MIC}_{90} \mathrm{~s}$ of compound 53 against MRSA and MSSA were more than $250 \mu \mathrm{g} / \mathrm{mL}(867.3 \mu \mathrm{M})$. As microdilution broth method was used to test MIC, we set $500 \mu \mathrm{g} / \mathrm{mL}$ $(1734.6 \mu \mathrm{M})$ as their $\mathrm{MIC}_{90} \mathrm{~s}$.

sion equations $y=-1.6745 x^{5}+56.143 x^{4}-741.93 x^{3}+4831.8 x^{2}-15531 x+19,805$ and $y=-1.1474 x^{5}+38.802 x^{4}$ $-515.39 x^{3}+3361.9 x^{2}-10789 x+13,706\left(x\right.$ is the $\mathrm{ACD} / \log \mathrm{P}$ or $\log \mathrm{D}_{7.40}$, and $y$ is the antimicrobial activities (MICs)), the theoretical MICs of these flavonoids can be calculated. Considering that many factors, such as determination method, concentration of bacterial suspension, and test medium used, may influence on the determination of $\mathrm{MIC}^{5}$, the results reported would fluctuate within a reasonable range of the actual values. Thereout, the predicted MICs ranged from $1 / 4 \times$ to $4 \times$ the determined one were acceptable (marked as A), especially those ranged from $1 / 2 \times$ to $2 \times$ the determined one, were considered as complete coincidence (marked as C) since the MICs were generally determined by double dilution method ${ }^{22}$. Simultaneously, those more than or equal to the minimum value when the determined MICs were no upper limit were also regarded as complete coincidence (marked as C). Otherwise, those were unacceptable (marked as U). The results (Table 8) indicated that the predicted MICs were in acceptable or complete coincidence with the measured ones for approximate $85.3 \%$ flavonoids. Although the antibacterial activities of ten flavonoids (14.7\%) are unsatisfactorily predicted, there are six compounds with the predicted MICs falling into the range of $1 / 8 \times$ to $8 \times$ determined ones. This together indicated that the MICs of most flavonoids against gram-positive bacteria can be roughly calculated from their $\mathrm{ACD} / \log \mathrm{P}$ or $\log \mathrm{D}_{7.40}$ although the predicted values are not in accordance with their tested ones for a few flavonoids. At least, these indicated that the $\mathrm{ACD} / \log \mathrm{P}$ or $\log \mathrm{D}_{7.40}$ is a key factor for the inhibitory activities of plant flavonoids against gram-positive bacteria. 


\begin{tabular}{|c|c|c|c|c|c|}
\hline \multirow[b]{2}{*}{ Compounds } & \multirow[b]{2}{*}{ CLogP $\mathrm{P}^{\mathrm{a}}$} & \multirow[b]{2}{*}{$\mathrm{ACD} / \log \mathrm{P}^{\mathrm{b}}$} & \multirow[b]{2}{*}{$\log D_{7.40}{ }^{b}$} & \multicolumn{2}{|l|}{$\operatorname{MIC}(\mu \mathrm{M})^{\mathrm{c}}$} \\
\hline & & & & MRSA G31 & MRSA G47 \\
\hline 55 & 5.58 & 6.52 & 6.33 & 14.7 & 7.4 \\
\hline 56 & 7.58 & 8.76 & 8.70 & 12.0 & 6.0 \\
\hline 57 & 3.78 & 4.72 & 4.51 & 16.2 & 32.3 \\
\hline 58 & 5.53 & 6.52 & 6.33 & 14.7 & 14.7 \\
\hline 59 & 4.94 & 5.89 & 5.67 & 28.4 & 7.1 \\
\hline 60 & 4.99 & 5.89 & 5.68 & 28.4 & 14.2 \\
\hline 61 & 5.71 & 6.60 & 6.35 & 29.4 & 14.7 \\
\hline 62 & 4.86 & 5.81 & 5.62 & 28.4 & 28.4 \\
\hline 63 & 4.81 & 5.81 & 5.62 & 28.4 & 28.4 \\
\hline 64 & 3.68 & 4.56 & 4.37 & 35.1 & 35.1 \\
\hline 65 & 6.25 & 7.24 & 7.06 & $122.4^{\mathrm{d}}$ & $122.4^{\mathrm{d}}$ \\
\hline 66 & 2.44 & 3.19 & 2.96 & 1469.2 & 734.6 \\
\hline
\end{tabular}

Table 6. Physico-chemical parameters and antimicrobial activities of compounds 55 to $\mathbf{6 6}^{15}$. ${ }^{\text {a The CLogP }}$ values were calculated using software ChemBioDraw Ultra 12.0. ${ }^{\mathrm{b}}$ The $\mathrm{ACD} / \log \mathrm{P}$ and $\log \mathrm{D}_{7.40}$ values were calculated using software ACD/Labs 6.0. 'MIC, minimum inhibitory concentration; MRSA G31 and G47, methicillin-resistant Staphylococcus aureus G31 and G47. ${ }^{\mathrm{d} B o t h}$ MICs of compound 65 against MRSA G31 and G47 were more than $25 \mu \mathrm{g} / \mathrm{mL}(61.2 \mu \mathrm{M})$. As microdilution broth method was used to test MIC, we set $50 \mu \mathrm{g} /$ $\mathrm{mL}(122.4 \mu \mathrm{M})$ as their MICs.

\section{Discussion and conclusion}

Flavonoids can be widely found in various parts of the plant, and their antibacterial activities have been paid more and more attention to, especially after some of them were discovered to have the potency to enhance the susceptibility of some antibiotics to bacteria ${ }^{4,5}$. Based on the related data of plant flavonoids reported, many related physicochemical parameters were calculated, using software ChemBioDraw Ultra 12.0 and ACD/Labs 6.0, for the discovery of the correlations between the physicochemical parameters and the MICs of flavonoids against gram-positive bacteria. Two regression equations between the $\mathrm{ACD} / \log \mathrm{P}$ or $\log \mathrm{D}_{7.40}(x)$ and the antimicrobial activities (MICs) $(y)$ were established as $y=-1.6745 x^{5}+56.143 x^{4}-741.93 x^{3}+4831.8 x^{2}-15531 x+19,805$ and $y=-1.1474 x^{5}+38.802 x^{4}-515.39 x^{3}+3361.9 x^{2}-10789 x+13,706$. From these two equations, the MICs of most flavonoids against gram-positive bacteria (mainly Staphylococcus and Bacillus) could be roughly calculated from their $\mathrm{ACD} / \log \mathrm{P}$ or $\log \mathrm{D}_{7.40}$, and their minimum value was predicted as approximately 10.2 or $4.8 \mu \mathrm{M}$. Considering that the experimental MICs would fluctuate within a reasonable range ${ }^{5}$, the minimum MIC of plant flavonoids will likely fall into the range from 2.6 to $10.2 \mu \mathrm{M}$, or from 1.2 to $4.8 \mu \mathrm{M}$, predicted from their ACD/ $\log \mathrm{P}$ or $\log \mathrm{D}_{7.40}$.

After all, the antibacterial activities of a compound to different pathogens are varied, and so these two regression equations, mainly valuable for Staphylococcus and Bacillus, may not always be suitable for flavonoids to other gram-positive bacteria. However, the acceptable range from $1 / 4 \times$ to $4 \times$ the determined MICs will increase the applicability of these two equations used for the prediction of plant flavonoids to other gram-positive bacteria. To say the least, if necessary, similar regression equations can be also established from the physicochemical parameters and the MICs to other gram-positive bacteria, of flavonoids. Thereby, we concluded that the MICs of most flavonoids against gram-positive bacteria can be roughly calculated from their physicochemical parameters ACD/LogP or LogD7.40.

Lipophilicity is a very important descriptor indicating membrane permeation ${ }^{23}$, and generally expressed as $\log \mathrm{P}$ which is valid only for a single electrical species. For ionizable drugs, $\log \mathrm{D}$ that refers to a $\mathrm{pH}$-dependent mixture of all electrical species presented at any given $\mathrm{pH}$ was regarded as a better descriptor reflecting the actual partitioning and lipophilicity ${ }^{24,25}$. Generally, most flavonoids contain two or more phenolic hydroxyl groups ${ }^{4-6}$, and present similar weak acidity with the pKa of 7.0 to 10.0. Thereby, their LogD will correspondingly decrease along with the increase of environmental $\mathrm{pH}$ from about 5.0. Considering the $\mathrm{pH}$ in human blood or in the media of MIC determination was approximately 7.40, their $\log \mathrm{D}$ at $\mathrm{pH} 7.40$ were selected. These together above indicate that the lipophilicity of plant flavonoids is a key factor for their inhibitory activities to gram-positive bacteria. As the lipophilicity is closely related to membrane permeability ${ }^{26}$, the tendentiously concave regression curves between the antibacterial activity and the $\log \mathrm{P}$ or $\log \mathrm{D}_{7.40}$ also indicate that the cell membrane is probably an important site of flavonoids acting on gram-positive bacteria.

Different antibacterial mechanisms of plant flavonoids were reported ${ }^{4-6}$, such as causing cell-membrane damage, inhibition on various synthase involving the nucleic acid synthesis, the bacterial respiratory chain, or the cell envelope synthesis. However, the results above suggested that the antibacterial activities of these plant flavonoids had no obvious relationship with the specific fragments of their structures, while presented great relationship with their lipophilicities. Simultaneously, the antibacterial activities of plant flavonoids will dramatically increase as the $\log \mathrm{P}$ or $\log \mathrm{D}$ increases from 2.5 to 4.0 which range the membrane permeability remarkably decrease while the affinity to lipid bilayer greatly increase ${ }^{27-29}$. According to this, plant flavonoids may not target specific synthases, but more likely to nonspecifically act on the cell-membrane bilayer or the respiratory chain to kill 


\begin{tabular}{|c|c|c|c|}
\hline Compounds & Parameters $^{\mathrm{b}}$ & Pathogenic bacteria $^{a}$ & Regression equation $\left(r^{c}\right)$ \\
\hline \multirow{6}{*}{1 to 19} & CLogP & \multirow{3}{*}{ S. aureus } & $y=-14.562 x^{5}+368.41 x^{4}-3689.3 x^{3}+18274 x^{2}-44755 x+43,369(0.8514)$ \\
\hline & $\mathrm{ACD} / \log \mathrm{P}$ & & $y=-6.1684 x^{5}+180.3 x^{4}-2090 x^{3}+12006 x^{2}-34172 x+38,560(0.7592)$ \\
\hline & $\log \mathrm{D}_{7.40}$ & & $y=-5.3777 x^{5}+151.88 x^{4}-1700.4 x^{3}+9430.9 x^{2}-25910 x+28,225(0.7331)$ \\
\hline & CLogP & \multirow{3}{*}{ B. subtilis } & $y=-13.392 x^{5}+345.58 x^{4}-3527.6 x^{3}+17792 x^{2}-44315 x+43,606(0.8093)$ \\
\hline & ACD/LogP & & $y=-8.1245 x^{5}+238.87 x^{4}-2785.6 x^{3}+16098 x^{2}-46081 x+52,265(0.8168)$ \\
\hline & $\log \mathrm{D}_{7.40}$ & & $y=-6.8012 x^{5}+193.67 x^{4}-2186.6 x^{3}+12230 x^{2}-33875 x+37,175(0.7660)$ \\
\hline \multirow{6}{*}{20 to 27} & CLogP & \multirow{3}{*}{ S. aureus } & $y=8.524 x^{4}-204.37 x^{3}+1846.7 x^{2}-7432.5 x+11,221(0.7878)$ \\
\hline & $\mathrm{ACD} / \log \mathrm{P}$ & & $y=-35.117 x^{5}+1129.5 x^{4}-14526 x^{3}+93407 x^{2}-300407 x+386,677(0.9998)$ \\
\hline & $\log \mathrm{D}_{7.40}$ & & $y=-32.854 x^{5}+1023.1 x^{4}-12742 x^{3}+79351 x^{2}-247194 x+308,250(0.9998)$ \\
\hline & CLogP & \multirow{3}{*}{ S. epidermidis } & $y=27.806 x^{4}-635.4 x^{3}+5428.8 x^{2}-20549 x+29,078(0.9228)$ \\
\hline & $\mathrm{ACD} / \log \mathrm{P}$ & & $\begin{array}{l}y=49.336 x^{5}-1560.6 x^{4}+19638 x^{3}-122806 x^{2}+381390 x-470,183 \\
(0.9999)\end{array}$ \\
\hline & $\log \mathrm{D}_{7.40}$ & & $\begin{array}{l}y=50.433 x^{5}-1541.1 x^{4}+18726 x^{3}-113020 x^{2}+338580 x-402,381 \\
(0.9999)\end{array}$ \\
\hline \multirow{9}{*}{21 to 24 , and 26 to 33} & CLogP & \multirow{3}{*}{ MRSA 6975} & $y=1.8495 x^{4}-35.986 x^{3}+255.94 x^{2}-793.24 x+933.27(0.9727)$ \\
\hline & $\mathrm{ACD} / \log \mathrm{P}$ & & $y=4.3462 x^{4}-100.91 x^{3}+865.04 x^{2}-3250.5 x+4550(0.9737)$ \\
\hline & $\log \mathrm{D}_{7.40}$ & & $y=3.9824 x^{4}-89.302 x^{3}+738.93 x^{2}-2679.6 x+3624.8(0.9724)$ \\
\hline & CLogP & \multirow{3}{*}{ MRSA 630} & $y=6.6617 x^{4}-108.73 x^{3}+631.7 x^{2}-1592.5 x+1668.4(0.8594)$ \\
\hline & $\mathrm{ACD} / \log \mathrm{P}$ & & $y=6.7373 x^{4}-144.65 x^{3}+1138.9 x^{2}-3954.4 x+5320.3(0.8317)$ \\
\hline & $\log \mathrm{D}_{7.40}$ & & $y=0.7482 x^{5}-12.599 x^{4}+58.825 x^{3}+49.926 x^{2}-1007.8 x+2110.7(0.8409)$ \\
\hline & CLogP & \multirow{3}{*}{ MRSA 6205} & $y=13.675 x^{4}-236.81 x^{3}+1465.8 x^{2}-3839.6 x+3692.3(0.8157)$ \\
\hline & $\mathrm{ACD} / \log \mathrm{P}$ & & $y=-1.087 x^{5}+45.877 x^{4}-674.86 x^{3}+4547.7 x^{2}-14384 x+17,445(0.7738)$ \\
\hline & $\log \mathrm{D}_{7.40}$ & & $y=-5.6301 x^{5}+162.46 x^{4}-1831.6 x^{3}+10059 x^{2}-26887 x+28,095(0.7847)$ \\
\hline \multirow{6}{*}{34 to 44} & CLogP & \multirow{3}{*}{ S. aureus } & $y=5.0053 x^{3}-76.039 x^{2}+329.45 x-293.29(0.9720)$ \\
\hline & $\mathrm{ACD} / \log \mathrm{P}$ & & $y=4.1508 x^{3}-74.07 x^{2}+387.42 x-479.73(0.9651)$ \\
\hline & $\log \mathrm{D}_{7.40}$ & & $y=3.2426 x^{3}-54.386 x^{2}+256.74 x-225.91(0.9643)$ \\
\hline & CLogP & \multirow{3}{*}{ B. subtilis } & $y=3.2197 x^{3}-46.825 x^{2}+177.07 x-40.407(0.9622)$ \\
\hline & $\mathrm{ACD} / \log \mathrm{P}$ & & $y=3.0215 x^{3}-52.494 x^{2}+254.63 x-216.12(0.9619)$ \\
\hline & $\log \mathrm{D}_{7.40}$ & & $y=2.3606 x^{3}-38.598 x^{2}+166.87 x-63.384(0.9607)$ \\
\hline \multirow{6}{*}{17,45 to 54} & CLogP & \multirow{3}{*}{ MRSA } & $y=-187.27 x^{3}+2012.3 x^{2}-7014.5 x+8045.6(0.9982)$ \\
\hline & $\mathrm{ACD} / \log \mathrm{P}$ & & $y=-141.22 x^{3}+2038.8 x^{2}-9673 x+15,205(0.9972)$ \\
\hline & $\log \mathrm{D}_{7.40}$ & & $y=-138.02 x^{3}+1870.5 x^{2}-8315.2 x+12,249(0.9964)$ \\
\hline & CLogP & \multirow{3}{*}{ MSSA } & $y=-186.51 x^{3}+1996 x^{2}-6936.4 x+7973.6(0.9830)$ \\
\hline & $\mathrm{ACD} / \log \mathrm{P}$ & & $y=-129.02 x^{3}+1872.9 x^{2}-8962.9 x+14,287(0.9789)$ \\
\hline & $\log \mathrm{D}_{7.40}$ & & $y=-146.22 x^{3}+1942.5 x^{2}-8495.7 x+12,386(0.9760)$ \\
\hline \multirow{6}{*}{55 to 66} & CLogP & \multirow{3}{*}{ MRSA G31 } & $y=-17.547 x^{5}+454.87 x^{4}-4632.7 x^{3}+23200 x^{2}-57189 x+55,596(0.9999)$ \\
\hline & $\mathrm{ACD} / \log \mathrm{P}$ & & $y=-12.103 x^{5}+371.48 x^{4}-4493.1 x^{3}+26798 x^{2}-78893 x+91,819(0.9999)$ \\
\hline & $\log \mathrm{D}_{7.40}$ & & $y=-10.79 x^{5}+322.43 x^{4}-3789.8 x^{3}+21934 x^{2}-62584 x+70,524(0.9999)$ \\
\hline & CLogP & \multirow{3}{*}{ MRSA G47 } & $y=-14.185 x^{5}+357.83 x^{4}-3530.1 x^{3}+17044 x^{2}-40327 x+37,493(0.9997)$ \\
\hline & ACD/LogP & & $y=-9.8483 x^{5}+294.98 x^{4}-3468.7 x^{3}+20038 x^{2}-56931 x+63,738(0.9997)$ \\
\hline & $\log \mathrm{D}_{7.40}$ & & $y=-8.6059 x^{5}+250.58 x^{4}-2858.5 x^{3}+15993 x^{2}-43945 x+47,542(0.9996)$ \\
\hline
\end{tabular}

Table 7. Regression equations between the physicochemical parameter $(x)$ and the antimicrobial activity $(y)$

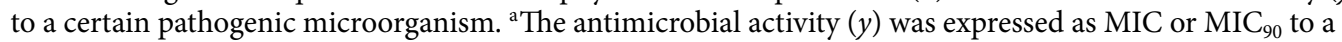
certain pathogenic microorganism. S. aureus, Staphylococcus aureus; S. epidermidis, Staphylococcus epidermidis; B. subtilis, Bacillus subtilis; MRSA, methicillin-resistant Staphylococcus aureus; MSSA methicillin-susceptible Staphylococcus aureus. ${ }^{\mathrm{b}} \mathrm{CLogP}$ was calculated using software ChemBioDraw Ultra 12.0, and ACD/LogP and $\log \mathrm{D}_{7.40}$ were calculated using software $\mathrm{ACD} / \mathrm{Labs} 6.0 .{ }^{\mathrm{c}} r$, correlation coefficients.

bacteria. This deduction was indirectly supported by many researches which were reviewed in three paper ${ }^{4-6}$, such as follows: (1) two mechanisms may be involved the interactions of flavonoids with lipid bilayers, which include the interactions at the membrane interface between the polar heads of phospholipids and the more hydrophilic flavonoids, and the partition of the more hydrophobic flavonoids in the interior of the lipid bilayer ${ }^{30}$; (2) nonspecific interactions of flavonoids with phospholipids can lead to the changes of the membrane properties ${ }^{31}$; (3) The increased activities of more lipophilic flavonoids are due to the enhanced membrane affinity of their long acyl chains $^{32}$; (4) Some lipophilic flavonoids can decrease the fluidity and integrity of cellular membrane to inhibit gram-positive bacteria ${ }^{33,34}$, such as sophoraflavanone $\mathrm{G}$ and 3-arylideneflavanones. 

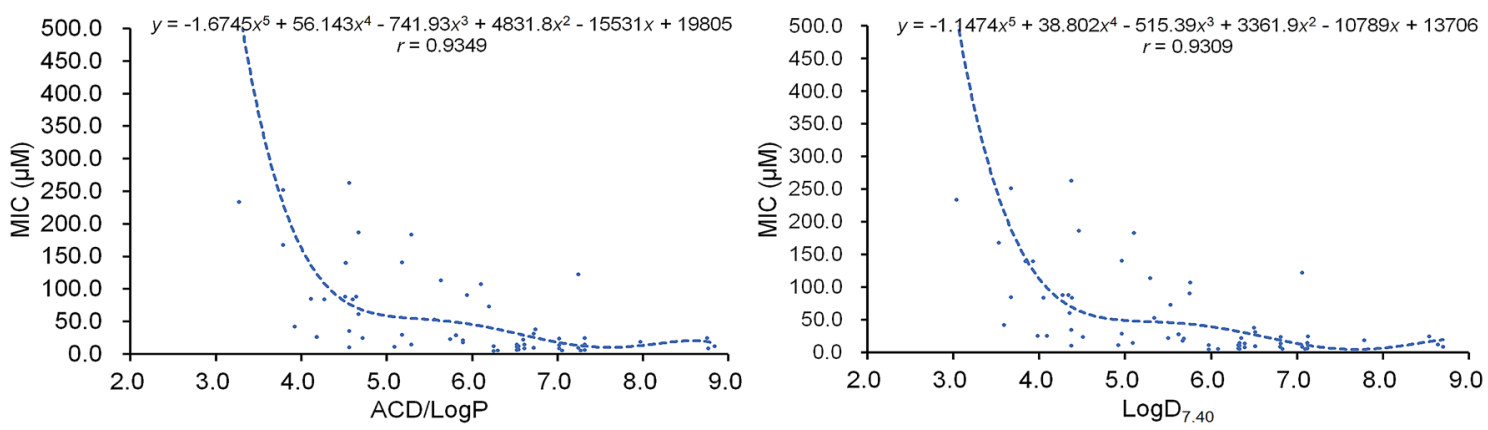

Figure 7. Polynomial regression analyses for the physicochemical parameters $\mathrm{ACD} / \log \mathrm{P}$ or $\log \mathrm{D}_{7.40}(x)$ and the average MICs (y) to gram-positive bacteria including S. aureus, S. epidermidis, or/and B. subtilis, of compounds 1 to 66 .

Although many other antibacterial mechanisms acting on various synthase for the nucleic acid or cell envelope syntheses were mentioned in these reviews ${ }^{4,6}$, two facts found from the researches of the cited literature are worth further discussing. First, most flavonoids used for mechanism exploration have the cLogP ranged from about 2.0 to 4.0 , and are easy to infiltrate into the bacterial cell, while they present very weak antibacterial activities with the MICs more than $250 \mu \mathrm{g} / \mathrm{mL}$. Second, most experiments were achieved by the determination of enzyme activities in vitro ${ }^{35,36}$, the molecular docking of flavonoids with various synthases ${ }^{37}$, the proteomics technology without the combination of related experiments and the consideration of first the chicken or the egg ${ }^{38}$. Another thing should be considered is whether some molecules can pass through the cell membrane and infiltrate into the bacterial cell or not. Moreover, previous works indicated the antibacterial activity to gram-positive bacteria was observed only four of fourteen flavonoids, while only four of seven flavonoids with DNA gyrase inhibition showed weak inhibitory activity to gram-positive bacteria ${ }^{20}$. Simultaneously, the authors pointed out that mechanisms other than DNA gyrase inhibition may also play a role in the antibacterial activity. Thereby, the conclusion that some of these flavonoids studied are potent inhibitors of DNA gyrase is worth reconsidering ${ }^{20}$. In fact, this work just right indicated that the inhibitory activity of flavonoids against gram-positive bacteria did not correlate with their in vitro DNA gyrase inhibition to a large extent. This was also supported by previous publication ${ }^{39}$. These together further confirmed that the cell-membrane should be the main region of plant flavonoids acting on Gram-positive bacteria, and which likely involving the disruption or damage of phospholipid bilayers, the inhibition of the respiratory chain or ATP synthesis, or some others.

According to the regression equations and above conclusions, the inhibitory activities of flavonoids to grampositive bacteria will increase when the alkyl especially isopentyl were introduced into the structures of flavonoids no matter carbon position it is introduced into. This can be interpreted that the introduction of alkyl would increase the lipophilicity of flavonoids or the LogP, and thereout increase their interactions with phospholipids of cell membrane. However, the introduction of too many alkyls will overmuch increase the LogP of these flavonoids, and which will lead their lipophilicities too large to pass through the hydrophilic region of phospholipid bilayers. This was proved by previous similar work ${ }^{26,32,40}$. On the contrary, the inhibitory activities of flavonoids to gram-positive bacteria will decrease when polar groups, such as hydroxyl and glycosyl, were introduced into their structures. This can be interpreted as that the excessive hydrophilicity of flavonoids will hinder its infiltration into phospholipid bilayers and interaction with hydrophobic region of cell membrane.

Based on the physicochemical parameters and MICs of various flavonoids, the regression equations and above conclusions were achieved. For a certain subclass of flavonoids, the regression equations with larger correlation coefficient can be established for their more accurate MIC predictions, and then can be further used for the structural design and optimization to obtain more efficient antibacterial activity.

As the inhibitory activities of plant flavonoids against gram-negative bacteria were reported less, it is difficult to draw a statistical conclusion. Considering that the cell envelope of gram-negative bacteria was different from that of gram-positive ones, it is worth further exploring whether the above regression equations and above conclusions are suitable for plant flavonoids against gram-negative bacteria. However, these can provide good references for their related researches. Referring to the above conclusions, the anti-MRSA activities of trimethylhydroquinone, vitamin $\mathrm{K}_{3}$ and carnosic acid were successfully predicted and verified by our laboratory, $\mathrm{y}^{9,41}$.

In conclusion, the MICs of most flavonoids against gram-positive bacteria can be roughly calculated from their physicochemical parameters $\mathrm{ACD} / \log \mathrm{P}$ or $\log \mathrm{D}_{7.40}$, and the lipophilicity is a key factor of plant flavonoids against gram-positive bacteria. Combined with the analyses of previous publications, the results also suggest that the cell membrane may be the main site of plant flavonoids acting on gram-positive bacteria, and which likely involves the damage of phospholipid bilayers, the inhibition of the respiratory chain or ATP synthesis, or some others. Base on this, the inhibitory activities and mechanisms of plant flavonoids to gram-positive bacteria were diagrammatically presented as Fig. 9. 


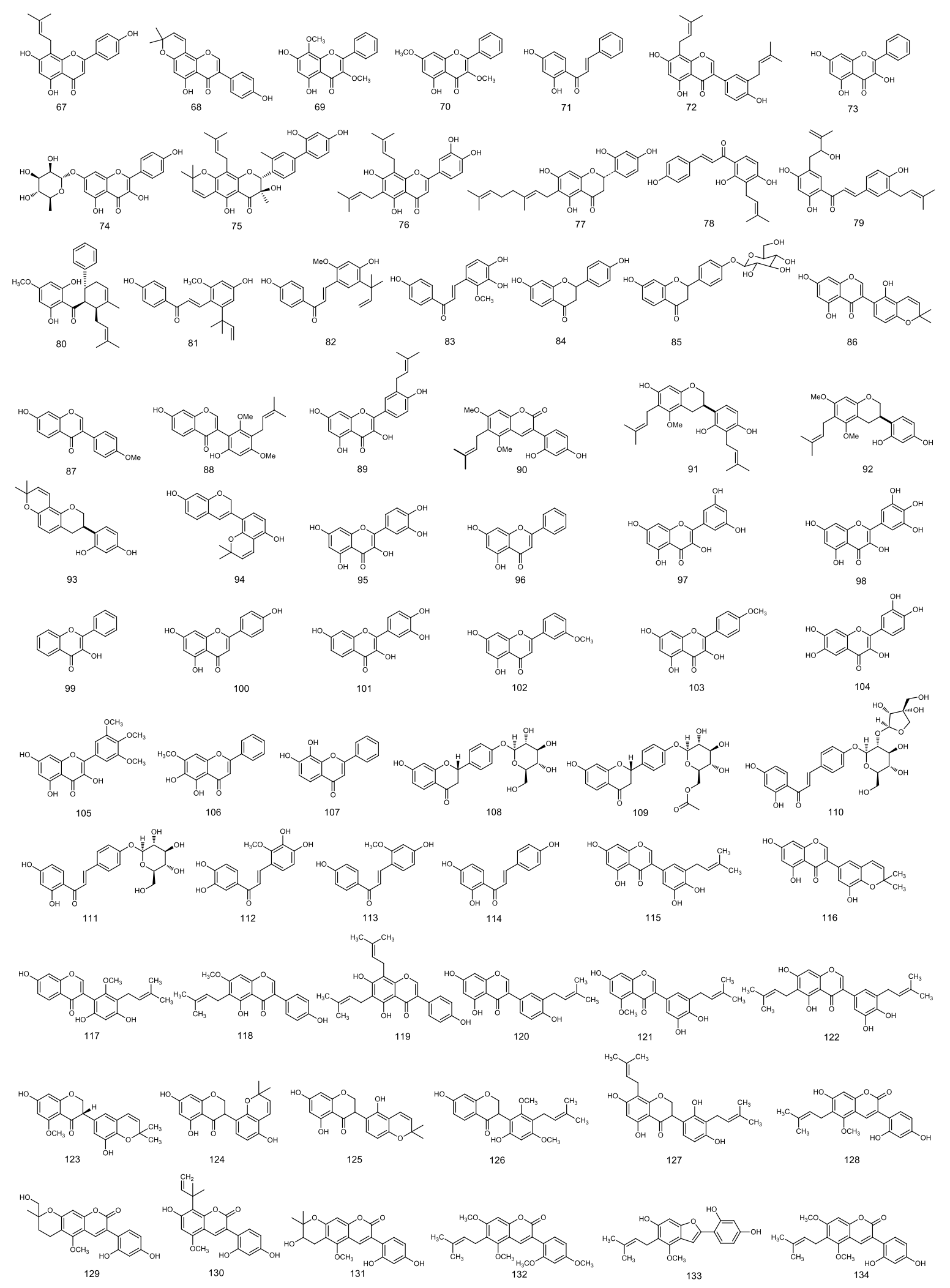

Figure 8. Chemical structures of compounds 67 to $134^{4,16-21}$. 


\begin{tabular}{|c|c|c|c|c|c|c|c|c|c|}
\hline \multirow[b]{3}{*}{ Compounds } & \multirow[b]{3}{*}{$\begin{array}{l}\text { Molecular } \\
\text { weight }\end{array}$} & \multicolumn{4}{|c|}{ Predicted antibacterial activities $^{\mathrm{a}}$} & \multirow{2}{*}{\multicolumn{2}{|c|}{$\begin{array}{l}\text { Measured antibacterial } \\
\text { activities }\end{array}$}} & \multirow[b]{3}{*}{ Coincidence } & \multirow[b]{3}{*}{ Reference } \\
\hline & & \multicolumn{2}{|c|}{ By $\log P$} & \multicolumn{2}{|c|}{ By $\log D_{7.40}$} & & & & \\
\hline & & $\log P$ & $\operatorname{MIC}(\mu \mathrm{M})$ & $\log D_{7.40}$ & $\operatorname{MIC}(\mu \mathrm{M})$ & $\begin{array}{l}\text { MIC }(\mu \mathrm{g} / \\
\mathrm{mL})\end{array}$ & $\operatorname{MIC}(\mu \mathrm{M})$ & & \\
\hline 67 & 338.35 & 4.20 & 121.21 & 3.77 & 162.30 & 62.5 & 184.7 & C & 16 \\
\hline 68 & 336.34 & 5.55 & 54.21 & 4.82 & 52.69 & 62.5 & 185.8 & A & 16 \\
\hline 69 & 314.29 & 2.16 & 2467.72 & 1.72 & 2794.56 & $\geq 200$ & $\geq 636.4$ & C & 17 \\
\hline 70 & 298.29 & 3.10 & 695.19 & 2.32 & 1381.83 & $\geq 200$ & $\geq 670.5$ & C & 17 \\
\hline 71 & 240.25 & 3.93 & 183.65 & 3.62 & 206.48 & $50-200$ & $208.1-832.5$ & C & 17 \\
\hline 72 & 406.47 & 7.33 & 14.22 & 6.89 & 19.22 & $1.56-3.13$ & $3.8-7.7$ & C & 4 \\
\hline 73 & 270.24 & 2.83 & 1030.88 & 2.16 & 1683.78 & $>125-240$ & $\begin{array}{l}>462.6- \\
888.1\end{array}$ & C & 4 \\
\hline 74 & 432.38 & 1.70 & 4166.24 & 0.76 & 7234.60 & $1-2$ & $2.3-4.6$ & $\mathrm{U}$ & 4 \\
\hline 75 & 542.62 & 8.63 & 23.00 & 8.17 & 13.80 & $2.3-37.5$ & $4.4-69.1$ & C & 4 \\
\hline 76 & 422.47 & 6.59 & 31.55 & 6.40 & 32.27 & $0.5-4$ & $1.2-9.5$ & A & 4 \\
\hline 77 & 424.49 & 6.60 & 31.25 & 6.42 & 31.74 & 2.9 & 6.8 & $\mathrm{U}$ & 4 \\
\hline 78 & 324.37 & 5.49 & 54.80 & 5.44 & 47.91 & $0.3-0.6$ & $0.9-1.9$ & $\mathrm{U}$ & 4 \\
\hline 79 & 408.49 & 5.95 & 48.36 & 5.70 & 45.79 & $0.6-1.22$ & $1.5-3.0$ & $\mathrm{U}$ & 4 \\
\hline 80 & 406.51 & 8.35 & 21.21 & 7.93 & 10.00 & $0.125-2$ & $0.3-4.9$ & A & 4 \\
\hline 81 & 338.4 & 4.95 & 61.35 & 4.82 & 52.69 & $3.13-16$ & $9.3-47.3$ & C & 4 \\
\hline 82 & \begin{tabular}{|l|}
338.4 \\
\end{tabular} & 4.95 & 61.35 & 4.82 & 52.69 & \begin{tabular}{|l|}
$3.13-6.25$ \\
\end{tabular} & \begin{tabular}{|l|}
$9.4-18.9$ \\
\end{tabular} & A & 18,19 \\
\hline 83 & 286.28 & 2.57 & 1471.41 & 2.44 & 1185.40 & $>25-100$ & $>87.3-349.3$ & C & 18,19 \\
\hline 84 & 256.25 & 2.76 & 1137.07 & 2.61 & 946.52 & $>100$ & $>390.2$ & C & 18,19 \\
\hline 85 & 418.39 & 0.61 & $11,968.2$ & 0.46 & 9405.99 & $>50$ & $>119.5$ & C & 18,19 \\
\hline 86 & 352.34 & 5.67 & 52.85 & 5.07 & 49.83 & 12.5 & 35.5 & C & 18,19 \\
\hline 87 & 268.26 & $3.15,16$ & 644.51 & 2.91 & 621.60 & $>25-100$ & $>93.2-372.8$ & C & 18,19 \\
\hline 88 & 382.41 & 5.38 & 55.79 & 5.12 & 49.51 & $>25-50$ & $>65.4-130.8$ & C & 18,19 \\
\hline 89 & 354.35 & $4.15,16$ & 130.39 & 3.48 & 258.70 & $12.5-25$ & $35.3-70.6$ & C & 18,19 \\
\hline 90 & 382.41 & 5.75 & 51.77 & 5.75 & 45.21 & $>50$ & $>130.8$ & $\mathrm{U}$ & 18,19 \\
\hline 91 & 424.53 & 6.32 & 39.42 & 6.32 & 34.31 & $3.13-6.25$ & \begin{tabular}{|l|}
$7.4-14.7$ \\
\end{tabular} & A & 18,19 \\
\hline 92 & 370.44 & 4.41 & 93.10 & 4.40 & 68.92 & $6.25-12.5$ & \begin{tabular}{|l|}
$16.9-33.7$ \\
\end{tabular} & A & 18,19 \\
\hline 93 & 324.37 & 4.18 & 124.77 & 4.18 & 88.60 & $6.25-12.5$ & \begin{tabular}{|l|}
$19.3-38.5$ \\
\end{tabular} & A & 18,19 \\
\hline 94 & 322.35 & 6.64 & 30.07 & 6.63 & 26.09 & $12.5-25$ & $38.8-77.6$ & C & 18,19 \\
\hline 95 & 302.24 & 2.07 & 2746.05 & 1.40 & 3919.38 & $>125$ & $>413.6$ & C & 20 \\
\hline 96 & 254.24 & 2.88 & 960.17 & 2.33 & 1364.52 & $>125$ & $>491.7$ & C & 20 \\
\hline 97 & 302.24 & 2.62 & 1376.51 & 1.95 & 2158.21 & 500 & \begin{tabular}{|l|}
1654.3 \\
\end{tabular} & C & 20 \\
\hline 98 & 318.24 & 2.11 & 2619.40 & 1.42 & 3839.98 & $62.5-125$ & 196.4-392.8 & $\mathrm{U}$ & 20 \\
\hline 99 & 238.24 & 3.76 & 242.43 & 3.74 & 170.26 & $>125$ & $>524.7$ & $\mathrm{U}$ & 20 \\
\hline 100 & 270.24 & 2.1 & 2650.61 & 1.57 & 3284.32 & $\geq 125$ & $\geq 462.6$ & C & 20 \\
\hline 101 & 286.24 & 2.52 & 1571.57 & 2.22 & 1564.90 & $>125$ & $>436.7$ & C & 20 \\
\hline 102 & 284.26 & 3.04 & 760.45 & 2.50 & 1096.06 & $>125$ & $>439.7$ & C & 20 \\
\hline 103 & 300.26 & 3.00 & 806.77 & 2.33 & 1364.52 & $>125$ & $>416.3$ & C & 20 \\
\hline 104 & 302.24 & 2.54 & 1530.86 & 2.14 & 1724.98 & $31.3-62.5$ & 103.4-206.8 & $\mathrm{U}$ & 20 \\
\hline 105 & 360.31 & 3.02 & 783.32 & 2.32 & 1381.83 & $>125$ & $>346.9$ & C & 20 \\
\hline 106 & 284.26 & 3.22 & 578.89 & 2.45 & 1170.12 & $>125$ & $>439.7$ & C & 20 \\
\hline 107 & 254.24 & 2.51 & 1592.25 & 2.19 & 1623.47 & $31.3-62.5$ & $122.9-245.8$ & $\mathrm{U}$ & 20 \\
\hline 108 & 418.39 & 0.61 & $11,968.2$ & 0.46 & 9405.99 & $>128$ & $>305.9$ & C & 21 \\
\hline 109 & 460.43 & 2.46 & 1699.00 & 2.31 & 1399.32 & $>128$ & $>278.0$ & C & 21 \\
\hline 110 & 550.51 & 2.24 & 2239.77 & 2.06 & 1897.96 & $>128$ & $>232.5$ & C & 21 \\
\hline 111 & 418.39 & 1.04 & 8107.91 & 0.87 & 6546.46 & $>128$ & $>305.9$ & C & 21 \\
\hline 112 & 302.28 & 2.36 & 1929.91 & 2.19 & 1623.47 & $>128$ & $>423.5$ & C & 21 \\
\hline 113 & 270.28 & 3.23 & 570.00 & 3.10 & 468.93 & $64-128$ & $236.8-473.6$ & C & 21 \\
\hline 114 & 256.25 & 3.40 & 436.17 & 3.26 & 366.65 & 128 & 499.5 & C & 21 \\
\hline 115 & 354.35 & 5.03 & 59.77 & 4.48 & 64.08 & $32-64$ & $90.3-180.6$ & C & 21 \\
\hline 116 & 352.34 & 4.63 & 73.82 & 4.07 & 102.86 & $32-64$ & $90.8-181.6$ & C & 21 \\
\hline 117 & 368.38 & 5.33 & 56.22 & 5.08 & 49.76 & 64 & 173.73 & A & 21 \\
\hline 118 & 352.38 & 5.69 & 52.59 & 5.40 & 48.13 & 16 & 45.41 & C & 21 \\
\hline 119 & 406.47 & 7.33 & 14.22 & 7.16 & 13.23 & 8 & 19.68 & C & 21 \\
\hline Continued & & & & & & & & & \\
\hline
\end{tabular}




\begin{tabular}{|c|c|c|c|c|c|c|c|c|c|}
\hline \multirow[b]{3}{*}{ Compounds } & \multirow[b]{3}{*}{$\begin{array}{l}\text { Molecular } \\
\text { weight }\end{array}$} & \multicolumn{4}{|c|}{ Predicted antibacterial activities ${ }^{\mathrm{a}}$} & \multirow{2}{*}{\multicolumn{2}{|c|}{$\begin{array}{l}\text { Measured antibacterial } \\
\text { activities }\end{array}$}} & \multirow[b]{3}{*}{ Coincidence $^{b}$} & \multirow[b]{3}{*}{ Reference } \\
\hline & & \multicolumn{2}{|c|}{ By $\log P$} & \multicolumn{2}{|c|}{ By $\log D_{7.40}$} & & & & \\
\hline & & $\log P$ & $\operatorname{MIC}(\mu \mathrm{M})$ & $\log D_{7.40}$ & $\operatorname{MIC}(\mu \mathrm{M})$ & $\begin{array}{l}\mathrm{MIC}(\mu \mathrm{g} / \\
\mathrm{mL})\end{array}$ & $\operatorname{MIC}(\mu \mathrm{M})$ & & \\
\hline 120 & 338.35 & 5.24 & 57.06 & 4.69 & 55.65 & $16-32$ & $47.3-94.6$ & C & 21 \\
\hline 121 & 368.38 & 4.70 & 69.97 & 4.27 & 79.27 & 64 & 173.7 & A & 21 \\
\hline 122 & 422.47 & 7.13 & 17.41 & 6.89 & 19.22 & 16 & 37.9 & C & 21 \\
\hline 123 & 368.38 & 4.56 & 78.51 & 4.27 & 79.27 & $32-64$ & $86.9-173.7$ & C & 21 \\
\hline 124 & 354.35 & 5.47 & 54.98 & 5.21 & 49.04 & $32-64$ & $90.3-180.6$ & $\mathrm{C}$ & 21 \\
\hline 125 & 354.35 & 5.47 & 54.98 & 5.21 & 49.04 & 32 & 90.3 & C & 21 \\
\hline 126 & 384.42 & 4.83 & 64.65 & \begin{tabular}{|l|}
4.67 \\
\end{tabular} & 56.23 & $32-64$ & $83.2-166.5$ & C & 21 \\
\hline 127 & 424.49 & 6.69 & 28.60 & 6.50 & 29.62 & 8 & 18.9 & C & 21 \\
\hline 128 & 368.38 & 5.99 & 47.55 & 5.98 & 41.74 & 16 & 43.4 & C & 21 \\
\hline 129 & 384.38 & 3.76 & 242.43 & 3.76 & 164.91 & $\geq 128$ & $\geq 333.0$ & C & 21 \\
\hline 130 & 368.38 & 5.61 & 53.56 & 5.59 & 46.85 & $16-32$ & \begin{tabular}{|l|}
$43.4-86.9$ \\
\end{tabular} & C & 21 \\
\hline 131 & 384.38 & 3.86 & 205.75 & 3.86 & 140.83 & $>128$ & $>333.0$ & C & 21 \\
\hline 132 & 410.46 & 5.79 & 51.17 & 5.79 & 44.71 & $>128$ & $>311.9$ & $\mathrm{U}$ & 21 \\
\hline 133 & 340.37 & 4.10 & 140.56 & 4.10 & 98.63 & 16 & 47.0 & A & 21 \\
\hline 134 & 382.41 & 5.75 & 51.77 & 5.75 & 45.21 & $>50-128$ & $\begin{array}{l}>130.8- \\
334.7\end{array}$ & A & 21 \\
\hline
\end{tabular}

Table 8. Comparison of predicted and reported antibacterial activities of some flavonoids. Antibacterial activities were expressed as MICs of flavonoids to gram-positive bacteria which include $S$. aureus, $S$. epidermidis and B. subtilis. ${ }^{\mathrm{a}} \mathrm{Log} \mathrm{P}$ and $\log \mathrm{D}_{7.40}$ were calculated using software $\mathrm{ACD} / \mathrm{Labs} 6.0 .{ }^{\mathrm{b}} \mathrm{C}$, Complete coincidence; A, Acceptable; U, Unacceptable.

\section{Methods}

Information and data. The structures, antimicrobial activities and other related information of plant flavonoids were unsystematically searched from Google academic search engine, and several databases SciFinder, Medline, Elsevier, ACS, ScienceDirect, Wiley Online Library, Springer-Link, and RSC, using keywords flavonoid and antimicrobial, or and antibacterial, and or and anti-MRSA. Furthermore, the relevant references in the obtained literature were also tracked. The structures, antibacterial activities, and other related information of flavonoids were collected from the obtained literature that can provide more than five or more flavonoids. As the antimicrobial activities of a certain compound against different pathogenic strains were varied, compounds reported in different papers were independently collected for the following analyses. Finally, the structures of selected compounds were drawn using software ChemBioDraw Ultra 12.0.

Simulation calculation of physicochemical parameters. The physicochemical parameters Gibbs energy, $\log$ P, CLogP, MR, CMR and tPSA were calculated using software ChemBioDraw Ultra 12.0. Moreover, another software ACD/Labs 6.0 was also used for the calculations of physicochemical parameters $\log P, \log D_{7.40}$ and solubility (SolDB).

Data analysis and correlation establishment. The physicochemical parameters and antibacterial activities of flavonoids reported in the same paper were respectively listed in a table, even those of the same compound. The regression analyses between the calculated values of each parameter and the antimicrobial activities (expressed as MICs) of all compounds in a table were respectively performed using Microsoft Excel software. It is noting that compounds without related antimicrobial information were not considered for the regression analyses, while they can be used for the following discussion. The physicochemical parameters significantly correlating with the antimicrobial activities were selected for the further analyses of correlations between the physicochemical parameters and antimicrobial activities of flavonoids.

Verification. Some other flavonoids were searched from above several databases, and the chemical structures of various flavonoids presented in previous publications were also drawn using software ChemBioDraw Ultra 12.0. The physicochemical parameters $\log P$ and $\log D_{7.40}$ of these flavonoids were respectively calculated by software ACD/Labs 6.0, and then their antimicrobial activities (MICs) were respectively predicted using the above regression equations. Comparing with the predicted MICs with the determined one, the regression equations can be verified. 


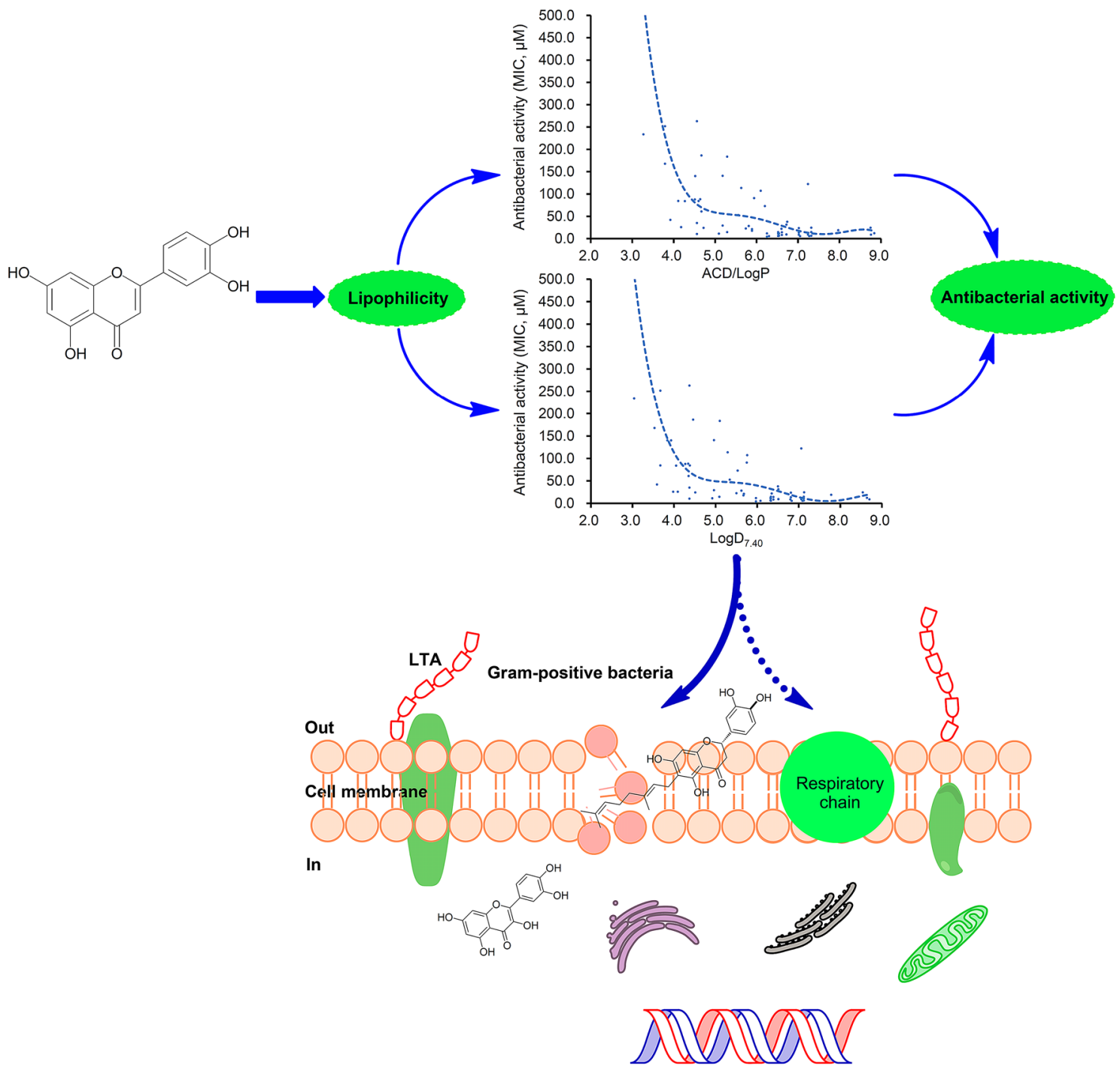

Figure 9. Diagrammatic presentation for the inhibitory activities and mechanisms of plant flavonoids to grampositive bacteria.

\section{Data availability}

The datasets generated during and/or analyzed during the current study are available from the corresponding author on reasonable request.

Received: 2 March 2021; Accepted: 6 May 2021

Published online: 18 May 2021

\section{References}

1. Laxminarayan, R., Sridhar, D., Blaser, M., Wang, M. \& Woolhouse, M. Achieving global targets for antimicrobial resistance. Science 353, 874-875 (2016).

2. Kurosu, M., Siricilla, S. \& Mitachi, K. Advances in MRSA drug discovery: where are we and where do we need to be?. Exp. Opin. Drug Discov. 8, 1095-1116 (2013).

3. Xu, X. et al. Synergistic combination of two antimicrobial agents closing each other's mutant selection windows to prevent antimicrobial resistance. Sci. Rep. 8, 7237 (2018).

4. Górniak, I., Bartoszewski, R. \& Króliczewski, J. Comprehensive review of antimicrobial activities of plant flavonoids. Phytochem. Rev. 18, 241-272 (2019).

5. Cushnie, T. P. T. \& Lamb, A. J. Antimicrobial activity of flavonoids. Int. J. Antimicrob. Agents 26, 343-356. https://doi.org/10.1016/j. ijantimicag.2005.12.002 (2005).

6. Xie, Y., Yang, W., Tang, F., Chen, X. \& Ren, L. Antibacterial activities of flavonoids: structure-activity relationship and mechanism. Curr. Med. Chem. 22, 132-149. https://doi.org/10.2174/0929867321666140916113443 (2015).

7. Xu, X. et al. Synergistic combination of two antimicrobial agents closing each other's mutant selection windows to prevent antimicrobial resistance. Sci. Rep. 8, 7237. https://doi.org/10.1038/s41598-018-25714-z (2018).

8. Yuan, G. et al. Azalomycin $\mathrm{F}_{5 \mathrm{a}}$, a polyhydroxy macrolide binding to the polar head of phospholipid and targeting to lipoteichoic acid to kill methicillin-resistant Staphylococcus aureus. Biomed. Pharmacother. 109, 1940-1950 (2019). 
9. Yuan, G., Zhu, X., Li, P., Zhang, Q. \& Cao, J. New activity for old drug: In vitro activities of vitamin $\mathrm{K}_{3}$ and menadione sodium bisulfite against methicillin-resistant Staphylococcus aureus. Afr. J. Pharm. Pharmacol. 8, 364-371 (2014).

10. Kuroyanagi, M., Arakawa, T., Hirayama, Y. \& Hayashi, T. Antibacterial and antiandrogen flavonoids from Sophora flavescens. J. Nat. Prod. 62, 1595-1599 (1999).

11. Šmejkal, K. et al. Antibacterial C-geranylflavonoids from Paulownia tomentosa fruits. J. Nat. Prod. 71, 706-709 (2008).

12. Navrátilová, A. et al. Minor C-geranylated flavanones from Paulownia tomentosa fruits with MRSA antibacterial activity. Phytochemistry 89, 104-113 (2013).

13. Inui, S. et al. Solophenols B-D and solomonin: New prenylated polyphenols isolated from propolis collected from the solomon islands and their antibacterial activity. J. Agric. Food Chem. 60, 11765-11770 (2012).

14. Sasaki, H., Kashiwada, Y., Shibata, H. \& Takaishi, Y. Prenylated flavonoids from Desmodium caudatum and evaluation of their anti-MRSA activity. Phytochemistry 82, 136-142 (2012).

15. Tsuchiya, H. et al. Comparative study on the antibacterial activity of phytochemical flavanones against methicillin-resistant Staphylococcus aureus. J. Ethnopharmacol. 50, 27-34 (1996).

16. Edziri, H. et al. Antibacterial, antifungal and cytotoxic activities of two flavonoids from Retama raetam flowers. Molecules 17, 7284-7293. https://doi.org/10.3390/molecules17067284 (2012).

17. Sufian, A. S., Ramasamy, K., Ahmat, N., Zakaria, Z. A. \& Yusof, M. I. M. Isolation and identification of antibacterial and cytotoxic compounds from the leaves of Muntingia calabura L. J. Ethnopharmacol. 146, 198-204 (2013).

18. Fukai, T. et al. Antimicrobial activity of licorice flavonoids against methicillin-resistant Staphylococcus aureus. Fitoterapia 73, $536-539$ (2002).

19. Fukai, T. et al. Anti-Helicobacter pylori flavonoids from licorice extract. Life Sci. 71, 1449-1463 (2002).

20. Ohemeng, K. A., Schwender, C. F., Fu, K. P. \& Barrett, J. F. DNA gyrase inhibitory and antibacterial activity of some flavones(l). Bioorg. Med. Chem. Lett. 3, 225-230 (1993).

21. Hatano, T. et al. Phenolic constituents of Licorice. VIII. ${ }^{1)}$ Structures of glicophenone and glicoisoflavanone, and effects of Licorice phenolics on methicillin-resistant Staphylococcus aureus. Chem. Pharm. Bull. 48, 1286-1292 (2000).

22. Clinical and Laboratory Standards Institute. CLSI Document M07-A9. Methods for Dilution Antimicrobial Susceptibility Tests for Bacteria that Grow Aerobically: Approved Standard. 19th Edn. Wayne, Pennsylvania, 2012.

23. Malkia, A., Murtomaki, L., Urtti, A. \& Kontturi, K. Drug permeation in biomembranes: In vitro and in silico prediction and influence of physicochemical properties. Eur. J. Pharm. Sci. 23, 13-47 (2004).

24. Bhal, S. K., Kassam, K., Peirson, I. G. \& Pearl, G. M. The rule of five revisited: Applying log d in place of log p in drug-likeness filters. Mol. Pharm. 4, 556-560 (2007).

25. Hou, T. J., Zhang, W., Xia, K., Qiao, X. B. \& Xu, X. J. ADME evaluation in drug discovery. 5. Correlation of Caco-2 permeation with simple molecular properties. J. Chem. Inf. Comput. Sci. 44, 1585-1600 (2004).

26. Testa, B., Crivori, P., Reist, M. \& Carrupt, P. A. The influence of lipophilicity on the pharmacokinetic behavior of drugs: Concepts and examples. Perspect. Drug Discov. 19, 179-211 (2000).

27. Jaehde, U., Goto, T., de Boer, A. G. \& Breimer, D. D. B. Blood-brain barrier transport rate of quinoline antibacterials evaluated in cerebrovascular endothelial cell cultures. Eur. J. Pharm. Sci. 1, 49-55 (1993).

28. Le Brun, P. P. H., Fox, P. L. A., de Vries, M. E. \& Bodde, H. E. In vitro penetration of some b-adrenoreceptor blocking drugs through porcine buccal mucosa. Int. J. Pharm. 49, 141-145 (1989).

29. Tsuchiya, H. Membrane interactions of phytochemicals as their molecular mechanism applicable to the discovery of drug leads from plants. Molecules 20, 18923-18966 (2015).

30. Arora, A., Byrem, T. M., Nair, M. G. \& Strasburg, G. M. Modulation of liposomal membrane fluidity by flavonoids and isoflavonoids. Arch. Biochem. Biophys. 373, 102-109 (2000).

31. Matsumoto, Y. et al. Antibacterial and antifungal activities of new acylated derivatives of epigallocatechin gallate. Front. Microbiol. 3, 53 (2012).

32. Tsuchiya, H. \& Iinuma, M. Reduction of membrane fluidity by antibacterial sophoraflavanone G isolated from Sophora exigua. Phytomedicine 7, 161-165 (2000).

33. Budzynska, A. et al. Synthetic 3-arylideneflavanones as inhibitors of the initial stages of biofilm formation by Staphylococcus aureus and Enterococcus faecalis. Z. Naturforsch. C 66, 104-114 (2011).

34. Singh, S. P., Konwarh, R., Konwar, B. K. \& Karak, N. Molecular docking studies on analogues of quercetin with D-alanine: D-alanine ligase of Helicobacter pylori. Med. Chem. Res. 22, 2139-2150 (2013).

35. Wu, D. et al. DAlanine: D-alanine ligase as a new target for the flavonoids quercetin and apigenin. Int. J. Antimicrob. Agents 32, $421-426$ (2008).

36. Jeong, K. W. et al. Screening of flavonoids as candidate antibiotics against Enterococcus faecalis. J. Nat. Prod. 72, 719-724 (2009).

37. Elmasri, W. A. et al. Multitargeted flavonoid inhibition of the pathogenic bacterium Staphylococcus aureus: A proteomic characterization. J. Proteome Res. 16, 2579-2586 (2017).

38. Havsteen, B. Flavonoids, a class of natural products of high pharmacological potency. Biochem. Pharm. 32, 1141-1148 (1983).

39. Hansch, C. \& Fujita, T. $\rho-\sigma-\pi$ analysis. A method for the correlation of biological activity and chemical structure. J. Am. Chem. Soc. 86, 1616-1626 (1964).

40. Baláž, Š. Lipophilicity in trans-bilayer transport and subcellular pharmacokinetics. Perspect. Drug Discov. 19, 179-211 (2000).

41. Yuan, G., Li, P. \& Yang, H. Anti-MRSA activity of carnosic acid in rosemary. Chin. J. Mod. Appl. Pharm. 29, 571-574 (2012).

\section{Acknowledgements}

This work was financially supported by grants from the National Natural Science Foundation of China (No. 82073745,81960636 and 81660578).

\section{Author contributions}

G.Y. initiated the project, hypothesis and design, analyzed the data and obtained regression equations, wrote the manuscript text, took part in the search and collection of flavonoids data, and prepared the figures and tables; Y.G. performed the search and collection of flavonoids data, and took part in the preparation of figures and tables; H.Y., S.L., Y.S. and S.C. took part in the data processing and analysis. All authors reviewed the manuscript.

\section{Competing interests}

The authors declare no competing interests.

\section{Additional information}

Supplementary Information The online version contains supplementary material available at https://doi.org/ 10.1038/s41598-021-90035-7. 
Correspondence and requests for materials should be addressed to G.Y.

Reprints and permissions information is available at www.nature.com/reprints.

Publisher's note Springer Nature remains neutral with regard to jurisdictional claims in published maps and institutional affiliations.

(c) (i) Open Access This article is licensed under a Creative Commons Attribution 4.0 International cc) License, which permits use, sharing, adaptation, distribution and reproduction in any medium or format, as long as you give appropriate credit to the original author(s) and the source, provide a link to the Creative Commons licence, and indicate if changes were made. The images or other third party material in this article are included in the article's Creative Commons licence, unless indicated otherwise in a credit line to the material. If material is not included in the article's Creative Commons licence and your intended use is not permitted by statutory regulation or exceeds the permitted use, you will need to obtain permission directly from the copyright holder. To view a copy of this licence, visit http://creativecommons.org/licenses/by/4.0/.

(C) The Author(s) 2021 